\title{
Between Geostrategic Rivalry and Economic Competition
}

Emergence of a Pragmatic India-China Relationship

Jean-François Huchet

\section{(2) OpenEdition}

\section{Journals}

Electronic version

URL: http://journals.openedition.org/chinaperspectives/4073

DOI: $10.4000 /$ chinaperspectives.4073

ISSN: 1996-4617

\section{Publisher}

Centre d'étude français sur la Chine contemporaine

Printed version

Date of publication: 1 July 2008

Number of pages: $50-67$

ISSN: 2070-3449

\section{Electronic reference}

Jean-François Huchet, « Between Geostrategic Rivalry and Economic Competition », China

Perspectives [Online], 2008/3 | 2008, Online since 01 July 2011, connection on 28 October 2019. URL

http://journals.openedition.org/chinaperspectives/4073; DOI : 10.4000/chinaperspectives.4073

(C) All rights reserved 


\title{
Emergence of a Pragmatic
} India-China Relationship

\author{
Between Geostrategic Rivalry and Economic Competition ${ }^{(1)}$
}

JEAN-FRANÇOIS HUCHET

This article analyses the extent of the China-India diplomatic thaw since the early 1990s. Without ignoring the existence of multiple cooperation channels, or seeking to minimise the importance of the considerable achievements realised in recent years by the two governments towards normalising their relations, the article show that relations between the two Asian giants remain hamstrung by a series of geostrategic and economic rivalries. Despite fast growth in trade and in specific areas of economic cooperation, the normalisation of ties between Beijing and New Delhi does not yet constitute a genuine strategic partnership.

"In public, India and China expressed undying friendship, but on the ground each was working to protect its strategic interests." ${ }^{(2)}$

A fters three decades of "freeze" following the war between the two countries in November 1962, India and China resumed diplomatic and trade exchanges in the early 1990s. ${ }^{(3)}$ Almost 32 years passed between the official visit of Premier Zhou Enlai to India in $1956^{(4)}$ and that of Prime Minister Rajiv Gandhi to China in 1988. Since the beginning of the current decade, bilateral diplomatic relations have improved dramatically, with each year seeing several visits by heads of government or state, as well as by ministers. ${ }^{(5)}$ During Premier Wen Jiabao's visit to India in April 2005, the two sides signed an agreement entitled "strategic partnership for peace and prosperity." In 2006, the two sides marked "friendship year," and 2007 was declared "year of friendship through tourism." Exchanges of official visits led to diplomatic advances of a symbolic nature such as the reopening on 4 July 2006 of the Nathu La border pass between Sikkim and Tibet after 44 years of closure. Likewise in trade the two countries have experienced a substantial thaw, as bilateral commerce, which was negligible before 1991 ( $\$ 260$ million at best) is expected to reach $\$ 38$ billion dollars 2008. ${ }^{(6)}$

The contrast is arresting when one compares the period of tension and freeze that characterised Sino-Indian ties from the late 1950s with the multi-directional acceleration of official contacts since early this decade. While it's still too early to assess the real impact of this diplomatic warming, it's nev- ertheless interesting, given the growing weight of the two Asian giants on the world arena, to consider the nature and evolution of this bilateral relationship in the context of international relations and global trade. Have the two countries really buried the rivalry and mutual suspicion that stemmed from the 1962 military conflict? Are they embarking on a fraternal entente of the kind symbolised by the early 1950s slogan "Hindi-Chini Bhai-Bhai" ${ }^{(7)}$ that was so dear to Nehru? More generally, could these warming diplomatic and trade relations give rise to a strategic partnership similar to that between the United States and Britain, or between post-World War II Germany and France, leading to the emergence of an Asian regional integrating force and a major axis in international relations? On the economic

1. Another version of this article will be published in Jean-Luc Racine (ed), L'Inde et I'Asie (India and Asia), Paris, Editions du CNRS, due for publication in 2009.

2. For a description of India-China relations in the early 1950s, see Ramachandra Guha, India after Gandhi: The History of the World's Largest Democracy, London, Picador India, 2007, 172 pp.

3. On Labour Day, 1 May 1970, Mao Zedong buttonholed Indian charge d'affaires Brajesh Mishra and said, "How long are we going to be quarrelling like this? Let us be friends again." This statement marked the beginning of a thaw in bilateral relations, but six years passed before concrete results in the form of an exchange of ambassadors in 1976. Dipankar Banerjee, "Perceptions of China from India ," in Revista Portugesa de Estudos Asiaticos, Vol. 2, 2006, n¹0, pp. 19-34.

4. Premier Zhou Enlai visited New Delhi again in April 1960 with the specific mission of holding face-to-face talks with Prime Minister Jawaharlal Nehru on the boundary issue.

5. The last was Prime Minister Manmohan Singh's January 2008 visit, which following President Hu Jintao's trip to India in November 2006.

6. Drew Thomson, "Singh's Visit: Views from Beijing," China Brief, Vol. VIII, $n^{\circ} 4,14$ February 2008, pp. 8-10.

7. The slogan was launched during Zhou's visit in 1956 to signify brotherly ties between China and India. 
plane, for instance, one analytical trend (encapsulated in the expression "Chindia" $\left.{ }^{(8)}\right)$ argues that the complementary character of the two economies - "workshop of the world" (China) and "the globe's back office" (India) - could boost their technological cooperation and build a strategic partnership, leading to a major overhaul of the regional and global economic scene.

This article counsels caution with regard to media hyperbole as well as misleading conclusions drawn from the similarities of population size or pace of economic growth of the two countries. Without ignoring the existence of several channels of cooperation or seeking to minimise the importance of considerable achievements realised in recent years by the two governments towards normalising their relations, this article argues that pragmatism will prevail on both sides of the Himalayas. The first part of the article shows that the historical baggage of bilateral relations dominated by suspicion and conflict is far from being jettisoned, and that a number of problems that led the two sides to a military conflict still remain despite the altered regional and global geopolitical context. In the second part, devoted to economic matters, the article shows that the potential for strategic cooperation is limited to a few areas, whereas the economic rivalry between two countries is much greater and is unlikely to diminish in intensity or in the number of contentious issues in the coming years.

\section{Suspicions and geostrategic rivalries in bilateral relations}

The war that China unleashed on 20 October 1962 - while the world's attention was focused on the "Cuban Missile Crisis " between the United States and the Soviet Union lasted a mere 30 days, ${ }^{(9)}$ but it continues to haunt BeijingNew Delhi relations nearly half a century later. Quite apart from the territorial differences over recognising the McMahon line ${ }^{(10)}$ and the question of which side was responsible for sparking the war, ${ }^{(I I)}$ geopolitical tensions of a more general nature have persisted since the 1950s, despite transformations in the regional and international contexts. Moreover, the alliance between Pakistan and China, and India's backing of the Dalai Lama, continue to weigh heavily on Sino-Indian ties.

\section{The clash of two nationalisms and rivalries for Asian leadership}

We'll start with a review of the geopolitical tensions that dogged Beijing-New Delhi ties in the 1950s: The rivalry - never officially expressed - between India and China to head the movement of developing countries seeking to keep some independence vis à vis the United States and the Soviet Union contributed greatly to the deterioration in Beijing-New Delhi relations. Right from 1927, well before India's independence, Nehru had in a speech to the All India Congress Committee (the central decision-making body of the Congress party) referred to the role of India and China in fighting imperialism and promoting non-alignment. ${ }^{(12)}$ As is widely known, neutrality and peaceful coexistence became the pivot of India's foreign policy after independence. The democratic character of Indian polity and Nehru's aura on the international scene helped India project itself as the natural leader of the non-aligned movement, provoking jealousy and irritation among Beijing's Communist leaders. Several analyses of the causes behind the 1962 war attribute to China the desire to "teach a lesson" to Nehru and curtail India's ambitions of becoming a leader of nonaligned countries, especially in Asia. The question of leadership of the newly decolonising Asian non-aligned countries was thus already an issue that pitted the two countries against each other in the 1950s.

China had not been recognised by the United Nations, and while the two countries' internal economic situations allowed neither to project political influence in Asia, unambiguous international recognition helped Nehru's India assume a role in Asia that China, immersed in its own political turmoil, was quite incapable of playing. The war China unleashed consciously shattered Nehru's foreign policy ambitions for India. By forcing India to seek US military aid to counter the Chinese troops amassing in strength along the Assam plains, ${ }^{(13)}$ China exposed the limits of the non-alignment pol-

8. The expression has gained currency since early in the current decade. See for example Jairam Ramesh, Making sense of Chindia: Reflections on China and India, New Delhi, India Research Press, 2005

9. The demarcation line set in the Simla accord signed in 1914 with Tibet - without Chinese assent - by British foreign secretary for India, Henry McMahon.

10. See Neville Maxwell, India's China War, Pantheon Books, 1970, 475 pp, on New Delhi's responsibility in the conflict; see also John W. Garver, Why did China go to war with India in 1962? http://www.people.fas.harvard.edu/ johnston/garver.pdf.; and James Barnard Calvin, The China - India Border War (1962), Marine Corps Command and Staff College, April 1984, http://www.globalsecurity.org/military/library/report/1984/CJB.htm.

11. M. J. Akbar, Nehru: The Making of India, New Delhi, Lotus Rodi, 2002, p. 535 ff.

12. Realising the impossibility in both diplomatic and military terms of encroaching too deeply into Indian territory despite the Indian army's rout, Mao and Zhou ordered Chinese troops to halt their offensive and to retreat from some zones conquered during the conflict. See Neville Maxwell, op. cit; ; see also the memoirs of John K. Galbraith, who was US ambassador in India at the time of the 1962 conflict: Richard Parker, John Kenneth Galbraith: His Life, His Politics, His Economics, New York, Farrar, Straus, Giroux, 2005, 820 pp.

13. See especially the remarks of Richard B. Russel, Senate armed forces committee chairman, in Ramachandra Guha, op. cit., p. $340 \mathrm{ff}$. 


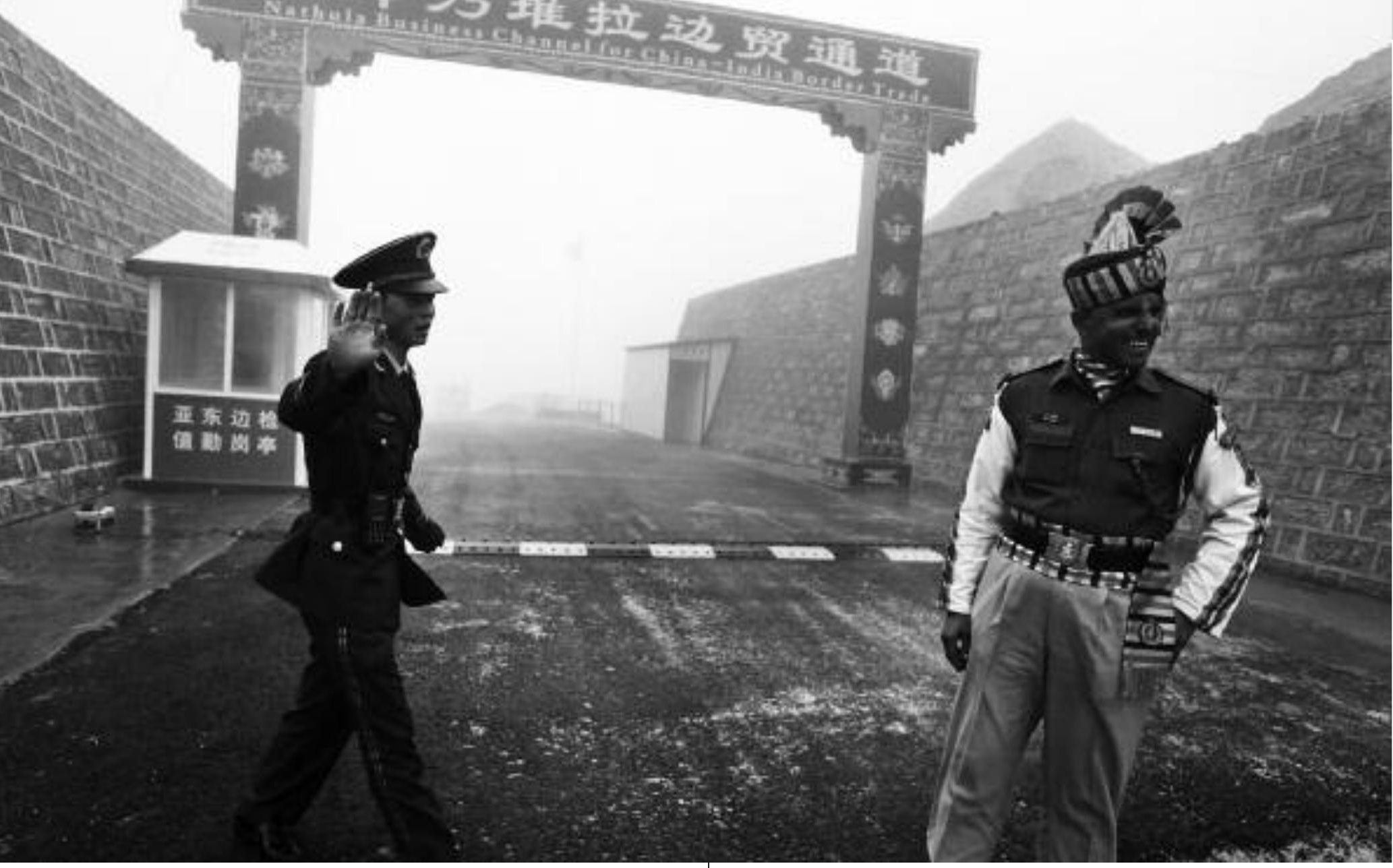

A Chinese soldier and an Indian soldier stand guard at the Chinese side of
the ancient Nathu La border crossing between India and China. When the
two Asian giants opened the 4,500-metre-high (15,000 feet) pass in 2006
to improve ties dogged by a bitter war in 1962 that saw the route closed for
44 years, many on both sides hoped it would boost trade. Two years on,
optimism has given way to despair as the flow of traders has shrunk to a
trickle because of red tape, poor facilities and sub-standard roads in India's
remote northeastern mountainous state of Sikkim.
@ AFP

icy Nehru touted. US military aid was extended on 20 November 1962 as the conflict was ending, and not without criticism from American political circles, which rebuked Nehru's lack of gratitude for America's food aid and his refusal to align New Delhi's position with Washington's against Communism. ${ }^{(14)}$ The conflict exposed to the world at large India's military and tactical failures in the face of China's determination and solidity. Nehru and his defence minister V. K. Krishna Menon became the butt of bitter and pointed attacks from the Indian political class, who considered them guilty of failing to perceive the extent of the Chinese threat. Nehru emerged from the conflict greatly weakened on both the foreign and domestic fronts: he had never believed war was imminent, despite repeated Chinese aggressions and warnings from Indian intelligence agencies. $^{(15)}$

This lack of clarity with regard to the Chinese Communist revolution stands in sharp contrast to the vision of the other major Indian leader, Vallabhbhai Patel. In a letter addressed to Nehru on 4 June 1949, i.e. before the birth of the People's Republic of China and Tibet's annexation in 1951, Patel had stressed the need:

to strengthen our position in Sikkim as well as in Tibet. The farther we keep away the Communist

14. M.J. Akbar's recent biography of Nehru clearly depicts his ambivalence towards China On the one hand Nehru seemed disturbed by the gathering diplomatic and military tensions in the Himalayas from the mid-1950s, but at the same time he believed that China, as a developing country concerned over its own diplomatic non-aligned independence and having suffered under colonial powers, would not launch an aggression against India. Many analysts attribute to then-defence minister V. K. Krishna Menon a portion of the blame for India's defeat. But it was, in the final analysis, Nehru who refused until the end to believe a Chinese attack was imminent. This was to a large extent the reason for the Indian troops' lack of preparedness. By the time the last-chance conciliation meeting with Zhou failed in November 1960, it was already too late for the Indian army, which was ill-prepared in a region that posed logistical challenges due to its difficult access. Indian military experts warned Nehru nearly 18 months before the start of the conflict of China's overwhelming logistic and military superiority thanks to strategic decisions Beijing had taken since the mid-50s to build major access routes for its military in the border region. See Akbar, op.cit., p. $533 \mathrm{ff}$.

15. B. Krishna, Sardar Vallabhbhai Patel, India's Iron Man, New Delhi, Rupa, 2005, p. 523 ff. 
forces (China), the better (for India). I anticipate that, as soon as the Communists have established themselves in the rest of China, they will try to destroy its (Tibet) autonomous existence."

In another letter to Nehru in November 1950, Patel said:

The Chinese Government has tried to delude us by professions of peaceful intentions [...] The final action of the Chinese, in my judgment, is little short of perfidy; [...] The tragedy of it is that the Tibetans put faith in us [...] and we have been unable to get them out of the meshes of the Chinese diplomacy or Chinese malevolence; [...] China is no longer divided. It is united and strong [...], Chinese ambitions in this respect not only cover Himalayan slopes on our side, but also include important parts of Assam [...] The danger from the north and north-east, therefore, becomes both communist and imperialist." ${ }^{(16)}$

Patel died in 1950 without seeing how prophetic his words proved to be. But his more pragmatic vision compared to Nehru's in matters of foreign policy, and his suspicion of Communist China (which was shared by a major portion of the Indian administration against Nehru's naiveté), did gain ground in India's foreign policy following the conflict with China. The "Chinese betrayal," India's military humiliation, and its impact on the last days of Nehru, who died in May 1964, ${ }^{(17)}$ left an indelible mark on India's collective memory. All this could well have been forgotten if the two countries had, like France and Germany after World War II, set out to actively seek the formation of a diplomatic axis in Asia by reverting to the idea Nehru had sought to promote in the 1950s. But nothing of that sort happened. Despite the grand declarations during recent exchanges of official visits, most of the reasons that led the two giant nations to a military conflict are still present, despite an altered global and regional geopolitical context.

The border conflict ${ }^{(18)}$ continues to poison bilateral relations. Many a skirmish occurred after the 1962 ceasefire. The two armies confronted each other twice, in 1967 (in Sikkim) and in 1984 (in the Sumdorong Chu valley in Arunachal Pradesh state). In 1987, the tone rose again in both capitals, sparking fears of another conflict. It was only in 1993 that New Delhi and Beijing signed an agreement on preserving "peace and tranquillity" along the line of control. Despite setting up a working group in November 2006 to resolve the border conflict, negotiations have yet to yield concrete results, and the occurrence of many recent incidents along the line of control shows that a resolution of the border issue is still far away. Indian leaders in Arunachal Pradesh state have on many occasions conveyed to New Delhi their fears over the reinforcement of Chinese military forces since 2005. Indian authorities have officially complained of hundreds of incursions by Chinese troops across the line of control since 2006. ${ }^{(19)}$ Nearly 65 incursions by the Chinese forces have been recorded since the start of 2008 in Sikkim, even though Beijing ostensibly acknowledged New Delhi's sovereignty over the region following a visit to China in 2003 by India's prime minister at the time, Atal Bihari Vajpayee. New Chinese demands over Sikkim could serve as a means to gain the upper hand in negotiations with India over another disputed region, that of Tawang in Arunachal Pradesh. Apart from possessing major mineral resources and being situated in the strategic Tibetan border, Tawang is a noted centre of Tibetan Buddhism. The Galden Namgey Lhatse monastery, where the 6th Dalai Lama was born, is the second largest in Tibetan Buddhism after the Potala in Lhasa, and members of the Tibetan government in exile made it an important base after their escape from Chinese control. It is therefore understandable that the Chinese communist leadership wants to recoup the territory (the Tibetan issue is further discussed below).

On the Indian side, Prime Minister Manmohan Singh visited Arunachal Pradesh just after his official trip to Beijing in January 2008. It was the first prime ministerial visit to the state in ten years. He sought to reassure local leaders - and demonstrate to Indian nationalists - that he would not abandon any part of Indian territory in negotiations with China to settle the border dispute. He also promised that he would release nearly two billion dollars towards infrastructure development in the border region, close to the line of control. This drew immediate protests from Beijing. ${ }^{(20)}$ On 31 May 2008, India also opened the Ladakh's Daulat Beg Oldi air

16. See Nehru's statement in Parliament on 8 November 1962, in which he strongly deplored what he saw as China's betrayal. It also amounted to an acknowledgement on his part of a major blunder in his foreign policy as it concerned China (Nehru was his own foreign minister). See Guha, op. cit., p. 334. Galbraith, the US ambassador, described in his memoirs Nehru's state of physical and mental shock in the immediate aftermath of the ceasefire in November 1962. See Parker, op. cit., p. $400 \mathrm{ff}$.

17. Chinese versions of the territorial conflict and of the 1962 war are thin on the ground. For instance, China has not revealed the number of casualties in its ranks.

18. The Indian government protested some 140 intrusions beyond the LoC by the Chinese army in 2007. Times of India, 6 April 2008.

19. Thomson, op.cit.

20. Sudha Ramachandran, "India takes the high ground against China," Asia Times, internet edition, 14 June 2008, http://www.atimes.com/atimes/South_Asia/JF14Df02.html. 


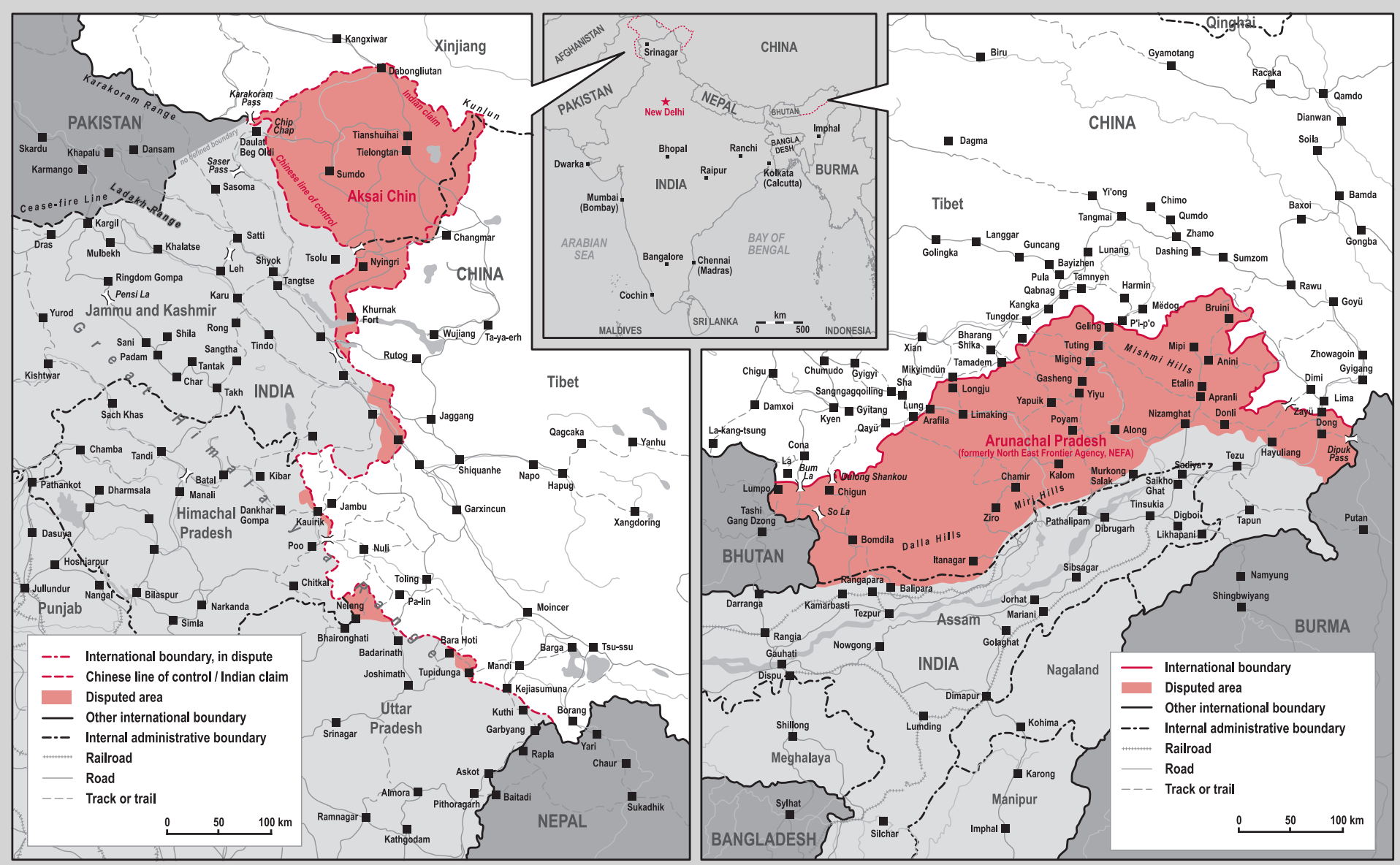

field, which had been closed for 43 years. The facility, situated close to the line of control at an altitude of more than 4,000 metres on the Aksai Chin plateau, and not far from the Karakoram highway linking Pakistan and China, is expected to help reinforce major Indian military logistics in the strategic zone. Beijing was quick to make known its displeasure over the move. The reopening of the Daulat Beg Oldi air strip is seen by Indian analysts as a response to several Chinese incursions across the line of control since 2005 that had gone unanswered by India. It also showed a willingness to boost India's military presence in the entire strategic region. ${ }^{(21)}$

It is worth noting that the border issue has become a kind of barometer of bilateral ties. Despite the thaw in relations, New Delhi and Beijing are still blowing hot and cold over the settlement of the border dispute, a function of evolution in the most important bilateral issues. The Indo-US rapprochement, especially on the civilian nuclear issue (see below), has led to a series of statements on China's part with regard to the border dispute. The most astounding though it merely reiterated a known Chinese stand - was that of the then Chinese ambassador Sun Yuxi, shortly after President Hu Jintao's India trip. The envoy said in November 2006 in a televised interview that Arunachal
Pradesh belonged to China, drawing a predictably furious response from India. ${ }^{(22)}$ On the Chinese side the border dispute is largely a geostrategic security issue of little concern to the public in comparison with attitudes toward Japan and Taiwan; on the Indian side, however, the 1962 humiliation left a great deal of nationalism and emotion invested. Failing a strong Chinese gesture, the Indian side will have only limited elbow room in negotiations.

As for rivalry over Asian leadership, economic and diplomatic clout has turned the wheel largely in Beijing's favour. China has a permanent seat in the UN Security Council, and its rapid economic development has led to active diplomacy with Asian countries since the mid-1990s. A recent article by Tarique Niazi points out that China has built a network of control over the Indian sphere of influence in Asia through its tentacles in ASEAN, the Shanghai Cooperation Organisation (SCO), and the South Asian Association for Regional Cooperation, ${ }^{(23)}$ and also through its highly active

21. For an analysis of the political repercussions in India from this statement, see The Hindu, 24 November 2006.

22. In which China has won observer status

23. Tarique Niazi, "Sino-Indian Rivalry for Pan-Asian Leadership," China Brief, Vol. 6, $n^{\circ} 4$, 15 February 2006. 
bilateral engagement with India's neighbours, including Nepal, Bangladesh, Myanmar, and of course Pakistan. ${ }^{(24)}$ Moreover, China has developed naval cooperation with many Asian countries to form a "pearl necklace" (in the Chinese media's words) in South and Southeast Asia through the establishment of a series of permanent military bases to secure energy supplies. ${ }^{(25)}$ Some of these bases, such as those in Chittagong in Bangladesh, Coco Islands in Myanmar, Habantota in Sri Lanka, Marao in the Maldives, and Gwadar in Pakistan, are very much in India's maritime "zone of influence."

Faced with all these actions on China's part, India has responded by obtaining dialogue partner status with ASEAN and observer status in the SCO, and launching some regional initiatives such as the "Mekong Ganga Cooperation"(26) in Nov 2000. Despite this Indian counteroffensive, China clearly dominates the diplomatic game of spheres of influence. India hasn't renounced its ambitions for Asian leadership, however. Nearly a half century after Nehru's death, and in an Asia transformed in the economic and political spheres, India continues, rightly or wrongly, to believe that its demographic weight, democratic values, and more recent economic dynamism could help it play a major role on the Asian stage. This hasn't gone unnoticed in Beijing, and the Sino-Indian rivalry in Asia continues to fuel mutual suspicion comparable to that between France and Prussia in Europe in the latter half of the nineteenth century. For now, Beijing enjoys a clear advantage.

The last issue that is symptomatic of this geostrategic rivalry concerns India's aspirations for a permanent seat on the UN Security Council. Beijing has blown hot and cold over the issue, never officially setting out a clear position. On 30 May 2008, during a BRIC (Brazil, Russia, India, China) summit at Yekaterinburg in Russia, China refused to sign a Russian-drafted final communiqué backing India's candidature. This refusal has been interpreted to mean either a change in China's position or its pursuit of a policy of control over the Indian sphere of influence. The handling of an issue so dear to India shows a deep chasm in the way of bilateral strategic cooperation.

\section{Fears of containment and "ménage à trois" with the United States}

Among the geopolitical tensions that bedevilled the two countries during the 1950s, China's fear of being encircled through India's strategic military alliance with the United States and the Soviet Union contributed greatly to the dete- rioration of bilateral ties. During the 1950s, Nehru succeeded in adroitly maintaining close relations with both sides of the Cold War (in spite of nettlesome relations with Secretary of State John Foster Dulles, a fervent anti-communist and initiator of the pact with Pakistan in February 1954). ${ }^{(27)}$ In 1959, Khrushchev openly criticised China's stands over Taiwan, Tibet, and the Sino-Indian border, and in July 1960, he recalled thousands of Soviet experts working in China. This rupture with the Soviet Union put China in a state of total isolation. The double alliance India was pursuing with the United States and the Soviet Union worried Chinese leaders, who feared being totally surrounded and forced to guard a new hostile front along the Himalayas in addition to the long border with the Soviet Union and that with Korea and the maritime borders with Taiwan and Japan. China was also worried about anti-Chinese agitation in Tibet. The Dalai Lama's departure from Lhasa in March 1959 and the welcome he received from the Indian government reinforced Chinese fears of possible military destabilisation in Tibet.

In going to war with India on 10 October 1962, China's aim was to neutralise with minimum force the dangers weighing on the vast frontier region in the south-west of the country so as to preserve sufficient military means to face up to US threats (over Taiwan) as well as Soviet ones. The United States eventually decided on 20 November 1962 to extend military backing to India. ${ }^{(28)}$ China, which had been aware for some days that it had achieved its aims and couldn't sustain a more ambitious invasion into Indian territory, declared a unilateral ceasefire ${ }^{(29)}$ and retreated from a good part of the territory conquered during the month-long war. The mission to militarily secure its south-west border had been realised. The Sino-Pakistan alliance, which had strengthened since 1963, helped Beijing complete the process in the south-west. Nehru's death in 1964, and the drift under his daughter, Indira Gandhi, towards populist socialism internally as well towards the Soviet Union externally, gradually distanced India from the United States. The elevation of Indo-Soviet

24. Olivier Zajec, "La Chine affirme ses ambitions navales" (China asserts its naval ambitions), Le Monde Diplomatique, September 2008, n654, pp. 18-19.

25. With six member countries - Cambodia, India, Laos, Myanmar, Thailand and Vietnam to promote regional cooperation in education, tourism, transport and culture.

26. Guha, op. cit., p. 159.

27. Faced with the massing of Chinese troops threatening the Assam plains, Nehru resigned himself to requesting US military assistance, which sparked much controversy within India as well as in the United States.

28. The ceasefire was declared a day before the official announcement of US assistance. Calvin, op. cit.

29. It was the subject of a bilateral agreement signed in August 2007. 
ties to a higher level from the mid-1960s continued to fuel Chinese fears of encirclement. Only in the 1980s and 1990s, after the collapse of the Soviet regime - a period of relative isolation for India - did China being to feel at ease. President Bill Clinton's visit to India in 2000, coming 22 years after Jimmy Carter's in 1978, revived containment fears in the Chinese leadership, which believed the United States was seeking to choke off China's emerging economic might through alliances with Japan, South Korea, and the countries of Central and Southern Asia. These fears deepened when a proposal for a nuclear accord was unveiled during Prime Minister Manmohan Singh's official US trip in July 2005. The proposal envisaged ${ }^{(30)}$ India (a non-signatory to the Nuclear Non-Proliferation Treaty - NPT) allowing inspectors of the International Atomic Energy Agency (IAEA) access to its nuclear energy production sites, ${ }^{(31)}$ along with a moratorium on nuclear tests. In exchange, India would gain access to US nuclear technology, ending 34 years of embargo on trade in nuclear material following India's first test in 1974. ${ }^{(32)}$ More generally, the agreement would allow India to officially enter the select group of nuclear powers while remaining outside of the NPT. The accord with the US required approval by the Indian Parliament, followed by the IAEA, the 45-nation nuclear suppliers group, and finally US Congress.

The first hurdle in the process affecting Indo-US ties was crossed with some difficulty. After a nine-month delay in schedule, and a bitter debate, India's ruling Congress party secured parliamentary assent on 22 July $2008,{ }^{(33)}$ thanks to backing from some small parties and independents and the abstention of some opposition MPs. This result came about despite the defection of the Communists (mainly members the Communist Party of India-Marxist), who had been backing the government from the outside. The delay fuelled criticism in the United States of India's inability to keep its word and the reluctance of its political class to seek a genuine rapprochement with Washington. Nevertheless, many observers insisted that the difficulties faced in the process of getting the deal approved by Indian MPs would temper the zeal of 2005 , and it would be possible to envisage a more realistic and pragmatic Indo-US relationship. ${ }^{\left({ }^{34)}\right.}$ More generally and beyond the nuclear issue, there have been extensive ideological departures in both the United States and India over the last few years on the question of bilateral ties. Washington has decided to pay serious attention to New Delhi's politi$\mathrm{cal}$, military, and economic weight in the region and to integrate it in strategic action plans for Asian security. ${ }^{(35)}$ On the Indian side, both the Bharatiya Janata Party (BJP) and the
Congress have worked for rapprochement with the United States since early this decade. ${ }^{(36)}$ This change has been reflected in a clear increase in bilateral cooperation in the strategic, military (joint exercises in the Indian Ocean), and economic domains.

While on the Chinese side the effort is to limit the effects of strategic and military encirclement, on the Indian side the rapprochement with the United States is aimed at directly limiting Chinese influence in Asia. One analyst of India's foreign policy put it this way:

\section{More than the sops offered by the United States, it is the stick being wielded by China that is powering the current Indian sprint toward a substantive strategic partnership with the United States, one that can only affect China's interests in Asia negatively. The Himalayan chill now enveloping Sino-Indian ${ }^{(37)}$ ties is creating summer warmth in India's relations with the other superpower, the United States. ${ }^{(38)}$}

This profound and lasting change in Indo-US ties has not escaped the attention of Beijing, which first fiercely attacked the nuclear accord, ${ }^{(39)}$ then sought to counter the American "charm offensive" in India by dangling the possibility of sig-

30. The agreement provides for placing 14 of India's 22 reactors under IAEA supervision.

31. For details of the agreement, see Jayshree Bajoria, "The U.S.-India Nuclear Deal," Council on Foreign Relations, February 2008, http://www.cfr.org/publication/9663/usindia_nuclear_deal.html?breadcrumb=\%2Fbios \%2Fbio\%3Fgroupby\%3D0\%26hide\%3D1\%26id\%3D13611\%26page\%3D3.

32. The ruling Congress, which needed to muster as many votes as it could to counter the defection of its allies, the communists, forced indisposed MPs to cast their vote and faced accusations from the BJP in parliament of having bought some opposition MPs' abstentions.

33. Amit Gupta, The U.S.-India Relationship: Strategic Partnership or Complementary Interests?, Strategic Studies Institute, February 2005, 55 pp.

34. R. Nicholas Burns, "America's Strategic Opportunity with India: The New U.S-India Partnership," Foreign Affairs, November-December 2007.

35. Edward Luce, In Spite of the Gods: The Strange Rise of Modern India, Random House, New York, 400 pp. See chapter 7, pp. 261-299.

36. This followed the statement in January 2007 by China's ambassador in India, Sun Yuxi, who claimed that the entire state of Arunachal Pradesh belonged to China.

37. M. D. Nalapat, "Himalayan chill over Sino-Indian Relations", UPI Asia.com, 30 July 2007,http://www.upiasia.com/Politics/2007/07/30/commentary_himalayan_chill_over _sinoindian_relations/1008/.

38. For China's official reaction to the Indo-US agreement, see Mohan Malik, "China responds to the U.S.-India Nuclear Deal," China Brief, Vol. 6, n7, 29 March 2006.

39. Boston Globe, 20 November 2006.

40. The announcement of a Sino-Indian nuclear agreement caused some irritation among "India sceptics" in Washington. Among the many criticisms already aired following the Indo-US accord were those insisting that New Delhi would make no change whatsoever to its non-alignment policy. It would appear that the Indo-US nuclear accord would provide Washington with limited leverage over New Delhi's options of obtaining similar technologies from China. See Jayshree Bajoria, "The U.S.-India Nuclear Deal," Council on Foreign Relations, February 2008. 
nificant civilian nuclear cooperation. ${ }^{(40)}$ The announcement of this proposal in November 2006 has yet to be followed up by any tangible move on Beijing's part. Although many in the Chinese military were hesitant about the gesture, Beijing may have hoped that the announcement of a potential cooperation would boost the numbers of Indian MPs opposed to the Indo-US nuclear agreement. China was also aware that the mere announcement of such a proposal could ignite "India sceptics" in Washington. ${ }^{(41)}$ Since the US-India agreement was signed in 2005, many in Washington have questioned the usefulness of US attempts to forge a strategic partnership with a country that does not wish to make the slightest changes to its policy of non-alignment, and which would remain, as during the Nehru and Indira Gandhi years, insensitive to US strategic initiatives. The 22 July 2008 vote in the Indian parliament backing the nuclear accord with the United States appears to have calmed the waters in Washington and frustrated Beijing's attempts to destabilise the Congress party by stoking a defection of its Communist allies.

The next three hurdles were crossed without great ado: The IAEA and the Nuclear Suppliers Group (NSG) rapidly gave their green lights after the Indian parliament vote, and the agreement gained the approval of the US Congress on 1 October 2008.

Beijing will henceforth be in a more uncomfortable position in countering the strategic repercussions of the Indo-US rapprochement. All the same, Beijing could decide to cooperate earnestly with India so that the United States does not become India's only and privileged partner in nuclear issues. Engaging in nuclear cooperation with India would also help Beijing test New Delhi's non-aligned credentials. And being "courted" by both Washington and Beijing on the issue, New Delhi might be tempted to play them off each other for higher stakes. However, keeping equidistant ties with Washington and Beijing and pursuing non-alignment would be a difficult balancing act for New Delhi. The United States would need some proof and gestures of exclusive loyalty from India in order to subdue Washington sceptics. Any perception in Washington that New Delhi was trying to play the big powers against each other could recoil and discredit India (as in the past) in its role of new Asian strategic partner.

This "ménage à trois," which is clearly transforming strategic relations in Asia in a deep and abiding way, could have surprises in store. Beijing holds many advantages - close ties with Pakistan, weight in the UN, special relations with ASEAN, and economic might in the region - to counter India's influence. But as the nuclear issue has clearly shown, after a 30-year hiatus, China's fears of containment through warming Indo-US ties could again become a crucial factor in Sino-Indian ties. This development can only exacerbate feelings of suspicion and pragmatism on both sides.

\section{The Tibet issue}

The Dalai Lama had considered requesting political asylum as early as 1956, when he was part of the official Chinese delegation during Premier Zhou Enlai's visit to India. SinoIndian relations were then in fine fettle. In an agreement signed with China in April 1954, India had officially recognised that Tibet belonged to China, and Nehru had signalled to the Dalai Lama that he did not wish to interfere in Sino-Tibetan affairs for fear of annoying the Chinese government. But by the time the Dalai Lama crossed the border in March 1959 and sought refuge in India, SinoIndian ties had already begun unravelling. China's construction in 1957 of roads for transporting military supplies to its borders with India, the publication of maps in 1958 claiming a part of Ladakh as Chinese territory, the exchange of letters between Nehru and Zhou in which the Chinese leader said in 1958 that Beijing did not recognise the McMahon line, and the first skirmishes along the border, had already led to deterioration of relations. The revolt by the Khampas in late 1958 was ruthlessly put down by the Chinese army, further convincing the Dalai Lama that his situation in Lhasa had become precarious. In this context of hostility with China, the Indian government this time accepted the Dalai Lama's request. His arrival in India in late March 1959 further vitiated Sino-Indian ties. In an interview with the American journalist Edgar Snow in October 1960, Zhou Enlai said the boundary dispute "came to the fore" after "the Dalai Lama had run away." He accused India of wanting to "turn China's Tibet region into a "buffer zone." He said: "They don't want Tibet to become a Socialist Tibet, as had other places in China," and that "the Indian side ... is using the Sino-Indian boundary question as a card against progressive forces at home and as capital for obtaining 'foreign aid." (42)

Nearly a half century after the Dalai Lama's arrival in India, the Tibet issue continues to bedevil bilateral ties.

41. In Look Magazine, 18 October 1960, quoted by Edgar Snow, The Other Side of the River: Red China Today, New York, Random House, 1963, and cited by Guha, op. cit, p. 319.

42. During Zhou's last pre-war visit in April 1960, finance minister Morarji Desai (who went on to become prime minister in 1977 after the end of the state of emergency declared by Indira Gandhi) told him: "Lenin sought asylum in the United Kingdom but nobody restricted his political activities." In Guha, op. cit., p. 318. 
The Sino-Indian modus operandi over Tibet remains fragile. Although the Indian authorities periodically pull up the Dalai Lama when he uses his Dharamsala headquarters for political activities to which China objects, he enjoys free movement in and out of India and manages to irritate the Chinese on a regular basis. ${ }^{(3)}$ The major uprising in March 2008 by the Tibetan population again upset whatever understanding existed between China and India on the Tibet issue. ${ }^{(44)}$ Despite the arrest of some Tibetans for staging "anti-China" activities on Indian soil, ${ }^{(4)}$ the Indian authorities have allowed demonstrations in many major cities, and the foreign ministry shed its reticence for once in calling for negotiations between the Dalai Lama and the Chinese authorities and a non-violent resolution of the troubles in Tibet. ${ }^{(46)}$

Yet another matter of Sino-Indian dispute and one linked to Tibet and the border issue is Beijing's claim to the whole of Arunachal Pradesh state in north-eastern India. China argues that the state was part of Tibet before the signing of the McMahon treaty in 1914. Tibet having become Chinese territory, Beijing believed Arunachal Pradesh belonged to it by right, insisting that Tibet had signed the McMahon treaty under British military pressure. From the late 1950s, Beijing claimed that the treaty stemmed from colonialism, was worthless, and that India, which had suffered under British domination, ought not to recognise it. During the Sino-Tibetan talks in July 2007, the Arunachal Pradesh issue was on the agenda for the first time. China voiced firm opposition to the decision taken by the Tibetan government in exile in December 2006 to accept India's sovereignty over Arunachal Pradesh. Beijing's accusation that the Tibetan government in exile had succumbed to pressure from Indian leaders, public opinion, and media was rejected in both Dharamsala and New Delhi. The Arunachal issue is another that complicates the settlement of Sino-Indian disputes.

\section{The Sino-Pakistan alliance}

Pakistan was the first Muslim country and the third noncommunist one to recognise the People's Republic of China in January 1950. As Indian academic Swaran Singh has pointed out, contrary to an oft-expressed view, China and Pakistan had embarked on a strategic partnership well before the Sino-Indian war of 1962 and the mutual defence agreement between Pakistan and United States signed in 1954. ${ }^{(47)}$ Starting in 1960, while the United States supplied military aid to Pakistan and backed the Chinese Nationalists in Taiwan, the Pakistanis supported the People's Republic in its rivalry with Taiwan to occupy a permanent seat in the UN Security Council. The Sino-Indian war certainly strengthened China's cooperation with Pakistan. They signed an agreement in 1963 on the border issue, and China backed Pakistan during its 1965 war with India by issuing warnings to New Delhi, and again after East Pakistan declared independence in 1971 with Indian military help, by using its newly won UN Security Council veto in 1972 to block Bangladesh's UN membership. China and Pakistan had been strengthening their military ties from the mid1960s, especially in nuclear matters. Following India's nuclear test in 1974, China was the main external backer of Pakistan's military nuclear programme, with the tacit understanding of the United States and indirect aid from European countries such as West Germany. ${ }^{(4)}$ Although the amount of China's military aid to Pakistan is quite difficult to estimate, given the secrecy that surrounds it, Western sources believe it to be among the most comprehensive and substantial that the People's Republic has supplied to any country since 1949. ${ }^{(49)}$ Pakistan, for its part, used its influence with the United States throughout the 1960s to get the China seat in the UN vacated by Taiwan and turned over to Communist China. Pakistan also played a major role in Sino-US rapprochement by facilitating Kissinger's secret trip to Beijing in July 1971, and Nixon's state visit in February 1972.

The warming of Sino-Indian diplomatic relations since the early 1990s has not dented Beijing-Islamabad ties. If anything, an economic facet has been added to their strong military and strategic ties since the early 1990s. Notable was the launch in 2002 of development of the deep-water port at Gwadar, close to the Strait of Hormuz, through which nearly 20 percent of global oil moves. The construction the Gwadar port, which is now close to completion, has been 80 percent funded by China (a total of $\$ 250$ million) and overseen mainly by state-owned China Harbour Engineering Co. Ltd., with nearly 350 Chinese engineers

43. See Robert Barnett, "Thunder from Tibet," New York Review of Books, Vol. 55, n9, 29 May 2008.

44. "India Detains Tibet Protestors," Time Magazine, 14 March 2008.

45. "India breaks silence, calls for talks on Tibet," The Times of India, 16 March 2008.

46. Swaran Singh (ed), China-Pakistan Strategic Cooperation, New Delhi, Manohar \& Centre de Sciences Humaines (CSH), 2007, 405 pp.

47. Savita Pande, "Nuclear Proliferation Concerns," in Singh (ed), op. cit., pp. 159-175.

48. See part II of Singh (ed), op. cit., pp. 137-330.

49. Associated Press, 13 May 2007. 
engaged in the project. ${ }^{(50)}$ In 2007, the Pakistani government entrusted operation of the port to the PSA Group of Singapore for 25 years, and conferred duty free status to $\mathrm{G} w a d a r$ for 40 years. Although the management agreement does not give Chinese ships exclusive rights to the use of Gwadar port, given its assistance in the construction and the solidity of Sino-Pakistan cooperation, China can anticipate good use of the strategic site to protect its energy supplies and boost its military presence. The project, emblematic of the strengthening of naval cooperation between Pakistan and China, has serious strategic and military implications for India, according to W. Lawrence S. Prabhakar. India will face a more muscular Chinese naval presence and the boosting of Beijing's efforts to stifle New Delhi's influence in the Indian Ocean region. ${ }^{(51)}$ More generally, although Sino-Pakistani relations have had to gradually adapt to the thaw in Sino-Indian ties, ${ }^{(52)}$ Pakistan remains a highly strategic card in China's foreign policy "game" in the region. A realignment with India or even a balancing act favouring New Delhi appears highly unlikely. Beijing may well deny it, but the fact remains that Pakistan remains a cat's paw limiting India's moves on the regional chessboard: the links between Pakistan's intelligence agencies and Islamic militants impeding a resolution of the Kashmir dispute (among other problems), military rivalry with India, communal conflicts between Hindus and Muslims that poisons Indian polity, the paralysis in the South Asian Association for Regional Cooperation caused by the Indo-Pakistan rivalry, and the access China has gained to Pakistan through the Strait of Hormuz, all constitute destabilising factors for India and will restrain its influence in the region. Moreover, China also enjoys a privileged entry into the Muslim world via Pakistan. Finally, the Indo-Pakistan rivalry allows China to keep its military presence relatively limited on its south-west flank. Despite the transformations in its relations with the United States and Russia, China must still ensure the security of its 22,722 kilometres of borders (the world's longest border, even exceeding Russia's) with 14 countries, including the 4,057 kilometre boundary with India (China's third longest after those with Mongolia and Russia). Moreover, China's Taiwan policy and the US military presence in Japan and South Korea preclude the concentration of too much military might in one border area.

For all these reasons, Sino-Pakistan relations can be expected to take precedence over Sino-Indian ties. As for $\mathrm{New}$ Delhi, although more and more voices call for a reasonable and rational view of Sino-Pakistan ties, ${ }^{(53)}$ the fact remains that the relationship is largely seen as a strategic alliance shrouded in secrecy and mainly aimed against India.

\section{Beyond complementarities in economic relations}

\section{A window-dressing pact between the "world's workshop" and the "world's back officen}

Among the analyses touting the potential for strategic economic cooperation between China and India, the alliance between the "world's back office" (India) and the "world's workshop" (China) is certainly one that has captured the imagination of many people. During a visit to India's "Silicon Valley," Bangalore, in April 2005, Premier Wen Jiabao went so far as to compare cooperation to "two pagodas, one hardware and one software; combined, we can take the leadership position in the world. When the particular day comes, it will signify the coming of the Asian century of the IT industry." (54)

Nevertheless the question arises as to how this specialisation in two different segments of the information industry, and more generally between two economic sectors (manufacturing in China and services in India, see Graphic 1), could induce greater bilateral cooperation. Few factors favour a deeper industrial cooperation between the two sides beyond superficial complementarities.

Firstly, cooperation would require each side to renounce over the long term the development on its soil of the segment in which it holds the lesser advantage, both absolute and comparative (in the sense David Ricardo meant). The current industrial policies of the two governments, as well the decisions of companies in each country, show a trend in exactly the opposite direction. Over the past few years, the two sides have, with varying degrees of success, striven to

50. W. Lawrence S. Prabhakar, "The Maritime Convergence," in Singh, op.cit., pp. 231-247; see also Zajec, op. cit.

51. China had a somewhat subdued reaction to India's 1998 tests. Several analysts have also pointed out that even during the decades of Sino-Indian freeze, China did not fire a single shot to defend Pakistan, either during the 1965 war or during the liberation of East Pakistan (Bangladesh) in 1971, contrary to the expectations of a number of Pakistan's top brass. See Guha, op. cit., p. 458.

52. See introduction by Singh (ed), op. cit.

53. Associated Press, 10 April 2005.

54. See Jon Sigurdson, Regional Innovation System (RIS) in China, Working Paper, 2004; and Ministry of Science and Technology of the PRC and OECD: OECD Reviews of Innovation Policies, China, Paris, OECD, 2007. 


\section{Graph 1. Comparison of GDP in India and China (2005)}

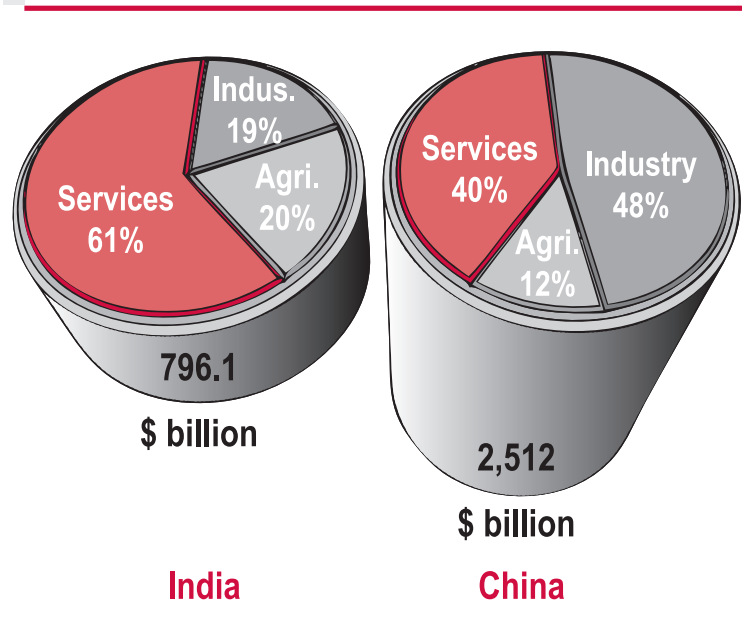

correct the economic development trajectories that led to an atrophy of industry in India's case and comparatively slower growth in services in China. (see Graphic 1). Taking the information industry as an example, it is clear that neither country has (as yet) given up developing on its soil the segments it currently lacks.

Aware of a backlog in the services sector, Chinese authorities at all levels have since the start of this decade boosted efforts to develop information technology- and biotechnology-based industries. Special Economic Zones such as Shenzhen and high technology development zones such as Zhongguancun (in Beijing) or Pudong (in Shanghai), to mention only a few, have made great strides in training, R\&D infrastructure, and intellectual property protection in order to promote the growth of these types of services. ${ }^{(55)}$

Similarly, India has taken measures to narrow the gap in the industrial domain. Indian companies have made increasing incursions into industrial sectors in which China enjoys a clear advantage in terms of economies of scale, export volume, and mastery of mass production techniques. ${ }^{(56)}$ This is the case in sectors such as automobiles, textiles (which in fact have suffered less from competition with China than initially feared with the termination of export quotas to developed countries in 2005), ${ }^{(57)}$ heavy industry (chemicals and steel), and more recently in the production of hardware for the information industry. These incursions have benefited from policies to protect India's domestic industry more in the home market than in exports. In terms of exports, especially textiles, Indian producers have found some niche markets in which they avoid direct competition with Chinese exports. ${ }^{(58)}$ Many projections also indicate that should the Indian government pursue a targeted liberalisation of foreign trade (reduction of import duties on intermediate products used in export production and lowering of transport costs), Indian industry could repeat the experience of China during the 1990s in benefiting from integration into the international division of labour through openness to more foreign direct investment and quickly develop a position of strength in manufacturing manpower. This would be all the more likely if India were to reform its labour laws (which currently restrict unskilled labour movement in the organised sector). Given India's demography - up until 2050 it will have an expanding active population younger than China's - the country will be in increasingly direct competition with China in manufacturing. ${ }^{(59)}$

Without waiting to realise these projections in the medium to long term, the Indian government has shown through its inaction on a Chinese proposal for a free trade agreement (FTA) that it has no desire to abandon those sectors in which China excels. First proposed by China in 2004, and broached every time Chinese leaders visited India, the FTA suggestion was rejected by both the BJP and Congress when in power. ${ }^{\left({ }^{60)}\right.} \mathrm{A}$ protectionist dimension is certainly evident in this refusal, notably pressure from the Indian business lobby (such as the Confederation of Indian Industry) against the agreement, but it also shows the government's desire to protect its industry from Chinese manufacturers and develop on the strength of the immense domestic market. India certainly needs to reform several elements of its trade and investment regimes. In fact, it has to find an appropriate balance, as China has done, between a "developmentalist" desire and the need to open itself to foreign presence and thus better integrate with the global economy.

More generally, China's domestic market is as large as India's. Unlike countries with small populations that need to

55. For an analysis of the strengths and weaknesses of Indian and Chinese foreign trade regimes, see T.P. Bhat et al, India and China: Trade Complementarities and Competitiveness, Bookwell, New Delhi, 2008.

56. The definitive lifting of quotas issued under the Multi-Fibre Arrangement was agreed under the GATT framework in 1973. The agreement on textiles and garments worked out under WTO auspices in 1995 took effect on 1 January 2005

57. V.N. Balasubramanyam and Wei Yingqi, "Textile and Clothing Exports from India and China: A Comparative Analysis," Journal of Chinese Economic and Business Studies, $n^{\circ} 1,2005$, pp. 23-37.

58. Betina Dimaraman, Elena lanchovichina, and Will Martin, China, India, and the Future of the World Economy: Fierce Competition or Shared Growth?, World Bank, Policy Research Working Paper $n^{\circ}$ 4304, August 2007, 25 pp.

59. See the latest statements indicating this stand in The Hindu, 22 April 2008, and Business Standard, 9 February 2008.

60. Jeffrey Frieden, Global Capitalism: Its Fall and Rise in the Twentieth Century, New York, W.W. Norton \& Company, $556 \mathrm{pp}$. 
specialise, vast domestic markets favour the development of the broadest range of industries and services with help from foreign direct investment. A country's comparative advantage and competitiveness in particular industrial sectors are not fixed in time; they can change and improve gradually over the years behind an evolving and selective protectionist wall. Like France, Germany, and the United States in the nineteenth century, ${ }^{\left({ }^{16}\right)}$ or Japan, Korea, and Taiwan, this was the policy China followed in the 1980s and 1990s before agreeing to significantly reduce tariffs in order to gain entry into the World Trade Organisation (WTO) in 2001. At the same time, China continues to maintain non-tariff barriers, to the chagrin of industrialised countries, in order to nurture a wide range of industries and services on its soil. A recent study showed that in India, too, many industrial sectors have gained a considerable international comparative advantage in the space of a few years. ${ }^{(62)}$ It should be stated here that if the day dawns when China and India dominate manufacturing or services, it will almost certainly take place in the context of competition, and not in the framework of a complementary partnership.

Secondly, even if current complementarities in economic activities (or trade) persist, they will not necessarily lead to closer industrial or technological cooperation between the two countries. The example of Japan and China shows this quite clearly. Despite rapid increases in trade - Japan is China's second largest trade partner after the EU - and the existence of complementarities in economic activities, the two countries have nevertheless failed to develop a strategic partnership in the technological or industrial sectors. Indeed, such partnerships are an exception rather than a rule in contemporary international economic relations generally. Technological and industrial cooperation among the EU countries was preceded and accompanied by a process of political integration that is unique in economic history today. It is also worth mentioning the great access enjoyed by Japanese and then Korean and Taiwanese firms to US technology following World War II. This cooperation was largely motivated by geopolitical considerations linked to the defence of American interests and the development of a "capitalist front" during the Cold War. ${ }^{\left({ }^{(3)}\right)}$ These countries were also within the US military's sphere of influence in the post-war period, which helped facilitate such cooperation until the 1970s. Once the Cold War ended, the United States demanded greater access for its products to the domestic markets of these countries, and the dismantling of non-competitive practices (including the links among industrial groups and banks such as the Keireitsu in Japan and the
Korean Chaebols), while imposing much stricter controls, even restrictions, on the transfer of technologies to companies in these countries. ${ }^{(64)}$

China-India ties fit neither the political integration model nor that of military protection or domination. It is therefore highly likely that current complementarities in economic structures will not lead to closer technological and industrial cooperation, but rather to more "conventional" progress in trade and investment exchanges, which in itself would be a great improvement over the past.

Thus the presence of firms such as China's Huawei in Bangalore or Tata Consulting in Pudong ${ }^{(65)}$ must be viewed with prudence and sobriety. China has become a formidable market globally. The growth in demand for information technology services on the part of Chinese firms as well as multinationals installed in China is such that it would be suicidal for Indian companies that lead in this domain not to boost their presence in China, all the more so as a number of multinationals that have been long-term clients of Indian firms have gained a major presence in China and continue to require servicing by Indian companies in the framework of traditional software sub-contracting.

In India, Chinese companies have sought to increase their presence since early this decade as part of a process of rapid multi-nationalisation. This is as imperative for them as it is for their Indian, Western, or Japanese counterparts. They have to strengthen and diversify their acquisition of technological competence or risk losing out not only to global competition but also within a domestic market that has opened under WTO membership. The firms have to "source" their technologies in the major world centres. As Bangalore and Hyderabad have emerged as two such centres, it would be normal for Chinese firms to establish bases there and seek out cooperation with leading Indian companies specialising in information technologies. The Wipro-Huawei joint ven-

61. Batra Amita and Zeba Khan, Revealed Comparative Advantage: An Analysis for India and China, ICRIER, Working paper, $n^{\circ} 168$, August 2005, New Delhi.

62. For instance, Japanese firms were allowed access to Bell Laboratories during the 1950s. See Mark W. Fruin, The Japanese Enterprise System: Competitive Strategies and Cooperative Structures, Oxford, Clarendon Press, 1994, 397 pp.; Akio Morita, Made in Japan: Akio Morita and Sony, New York, Penguin Books, 1988, 343 pp.; Shigeto Tsuru, Japan's Capitalism, Creative Defeat and Beyond, Cambridge, Cambridge University Press, 1993, 277 pp.

63. Takashi Inoguchi and Daniel I. Okimoto, The Political Economy of Japan, Volume 2: The Changing International Context, Stanford, Stanford University Press, 1988, 566 pp.

64. Tata Consulting opened its first China office in 2004 in Shanghai's Pudong technology development zone.

65. Gillian Goh Hui Lynn, China and India: Towards Greater Cooperation and Exchange working paper, Lee Kuan Yew School of Public Policy, National University of Singapore, 2006, $32 \mathrm{pp}$. 
Graph 2. Evolution of India-China bilateral trade (in billions of \$)

40

38.62

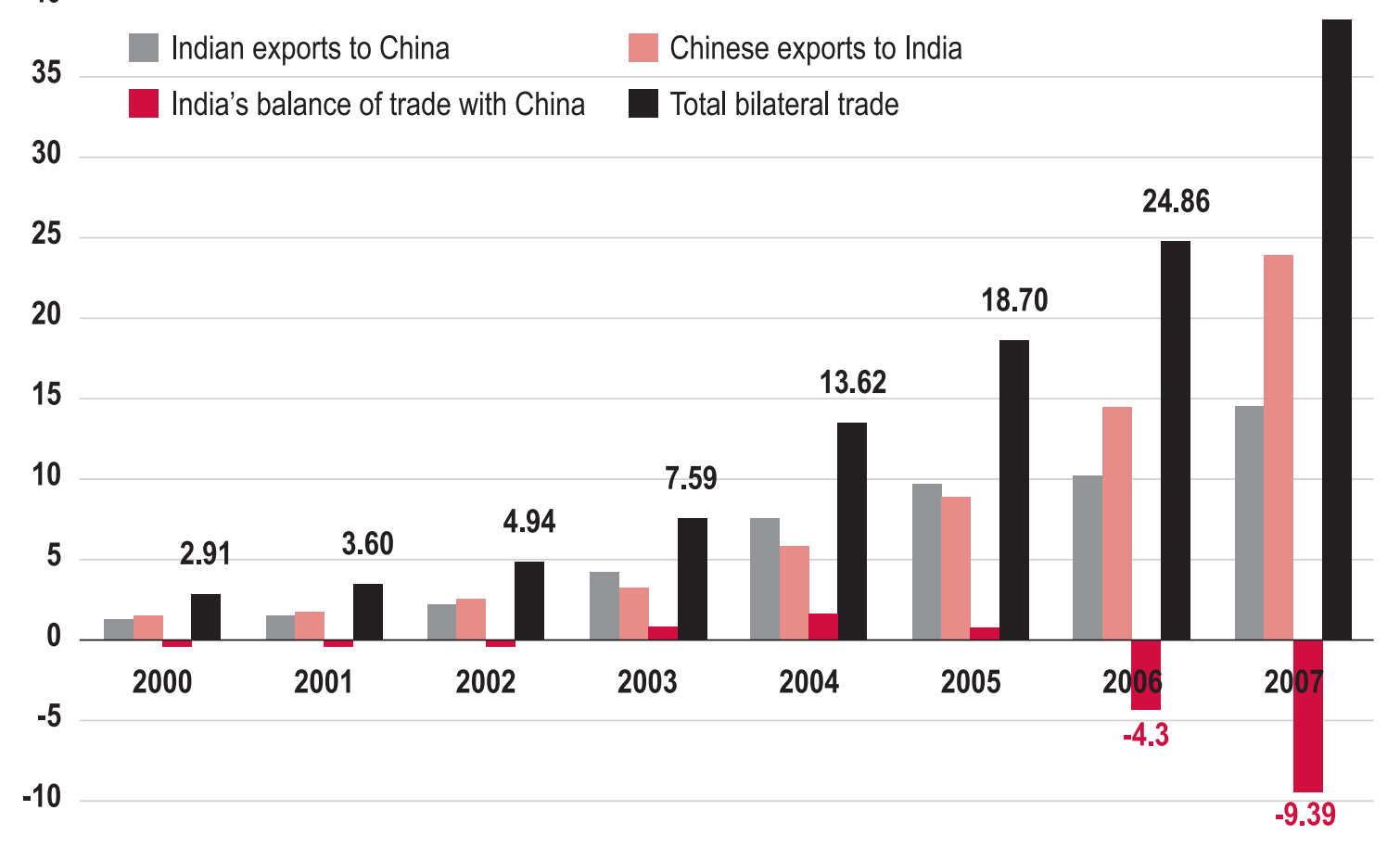

Source: United Nation Comtrade Database

ture that began in 2002 in the field of telecom routers is no different from the numerous commercial tie-ups between Indian firms and those from the United States, Europe, or Japan based in Bangalore or Hyderabad. The fact of it being a Sino-Indian JV is noteworthy as a "first" following a long freeze in the political and economic ties between New Delhi and Beijing. But in no way does it signal the development of closer bilateral strategic technological and industrial cooperation as some analysts suggest. ${ }^{(66)}$

\section{Current complementarities and future competition in trade relations}

As Table 2 shows, bilateral trade, which was almost nonexistent until the 1990s (\$260 million in 1991), has grown rapidly since early this decade. The targets set by the two countries in 2005 of achieving $\$ 20$ billion worth of trade by 2008 , and $\$ 30$ billion by 2010 , appears to have been surpassed: bilateral trade was already worth nearly $\$ 39$ billion in 2007. ${ }^{(67)}$

Research by M.S. Qureshi and Wan Guanghua ${ }^{(68)}$ into the foreign trade structures of both countries shows that the rapid rise in bilateral exchanges can be explained by increasing complementarities between India and China in recent years. To summarize, India mainly exports raw materials to China, which for its part ships mostly manufactured goods to India. Rapid economic growth in both countries, and the "reserves of complementarities" in products traded, increase the likelihood of rapid bilateral exchanges in the years to come, the authors say. India, for instance, has strong potential for increasing exports of leather and inorganic chemicals to China. ${ }^{\left({ }^{(6)}\right)}$ At the same time, China is capable of boosting its exports of telecommunication products and computers to India. Similarly, there is potential for intersectoral growth in steel, organic, and inorganic chemicals, as well as machinery. ${ }^{(70)}$ With a growth rate of 50 percent since 2000 , bilater-

66. Drew Thomson, "Singh's Visit: Views from Beijing," China Brief, Vol. 8, n4, February 14 , 2008, pp. 8-10.

67. M.S. Qureshi and Wan Guanghua, Trade Expansion of China and India: Threat or Opportunity, United Nations University, UNU-WIDER, Research Paper, $n^{\circ}$ 2008/08.

68. Bhat et al, op. cit

69. Qureshi and Wan, op. cit.

70. T.P. Bhat, "India - China Free Trade Area. Is it Feasible?", Working Paper, ISID, New Delhi, 2008, p. 20. 
al trade could total $\$ 60$ billion by the end of this decade, and $\$ 100$ billion by 2015. ${ }^{(71)}$

There are, nevertheless, many potential roadblocks to this expansion in bilateral trade, some of which could ignite trade disputes. The first is linked to the nature of Indian exports to China, mostly agricultural raw materials and minerals. Supplies of these natural resources are not unlimited, and given its domestic needs, India could be forced to limit the export of some products to China. This already occurred in July 2008 when Chinese importers, who had greatly boosted their imports of Indian iron ore, were faced with a new 15 percent tax on export of the raw material, which the government in New Delhi imposed in order to ensure adequate supplies to domestic steelworks. It would not be surprising if such protectionist measures multiply in India, given the enormous demand for mineral resources in China and the corresponding exponential demand from India's own industry.

The second limit is linked to the imbalance in trade that favours China, portending disputes. After having registered balanced trade and even a favourable turn between 2003 and 2005, India's deficit vis à vis China has risen rapidly since 2006; it was $\$ 9.39$ billion in 2007 (see Table 2), or 11 percent of India's total trade deficit. ${ }^{(72)}$ With a nearly 9.4 percent share of India's total imports by late 2007, China could well end up as India's top trade partner, overtaking the United States, if the trend in the first few months of 2008 holds. Despite a rapid rise in exports to China, India accounts for a mere 1.3 percent of China's total imports. Projections by foreign trade experts on the effects of a SinoIndian FTA show that China would benefit more. A 2007 study by the Institute for Economic Research in Munich showed that an FTA with a 100 percent reduction in tariffs would result in China's exports (with 2004 as base year) rising by 131 percent, against a mere 38 percent in India's case. ${ }^{(73)}$ This projection (on a static model without accounting for comparative advantages) and many other sectoral studies show that without a major improvement in the competitiveness of Indian goods, any simultaneous and proportional reduction in tariffs by Beijing and New Delhi would lead to a far higher increase in exports from China to India than in the other direction. ${ }^{(74)}$ It is therefore understandable that the Indian business lobby favours the status quo and the Indian government has dragged its feet on an FTA with China. As part of an FTA, if India's trade imbalance with China worsened, sections of Indian industry could suffer a serious competitive disadvantage, given the proportion of manufactured goods among China's exports to India. At a time when India is trying to play catch-up in industry, com- petition from China, which already poses problems for some sectors at current tariff levels, ${ }^{(75)}$ could further threaten takeoff plans should an FTA be implemented. It is thus not surprising that India has joined a number of other countries in refusing to grant market economy status to China in the WTO framework. By doing so, India is able to take steps to protect its market when it believes Chinese producers are "dumping" goods through prices depressed by their socialist heritage and disregard for laws such as those governing minimum wage and environmental protection.

In short, the rapid rise in exchanges is an encouraging and positive sign of warming Sino-Indian relations. It also ends the aberrant situation of what until early in this decade was a ridiculously tiny trade volume, given the rate of economic growth in the two countries, their physical proximity and the structural complementarities of their economies. However, as the example of Sino-Japanese ties shows, growing trade exchanges do not equate to strategic economic cooperation. Moreover, the sharp rise in trade could potentially bring an imbalance for India that could lead to disputes with China. Therefore India is most likely to continue protecting its industry and raw materials vis à vis China, which for its part is unlikely to be content with its current strong position in trade, but will keep pushing for an opening of India's domestic market to its goods. Tensions and conflicts are thus likely to accompany soaring bilateral trade.

\section{Parallel and competitive quests for new sources of raw material}

In January 2006, when Mani Shankar Aiyar, then minister for petroleum and natural gas, signed an agreement during an official trip to China, many analysts and commentators enthusiastically endorsed an energy alliance between the two sides. ${ }^{(76)}$ The agreement envisages extensive cooperation in the fields of oil and gas prospecting, refining, and distribution, and promotion of alternative energy. Above all, the two countries wished to express their willingness to eschew

71. India's exports in 2007 were valued at $\$ 151$ billion, against $\$ 230$ billion of imports, leaving a deficit of $\$ 79$ billion.

72. Swapan K. Bhattacharya and Biswa N. Bhattacharyay, Gains and losses of India-China Trade Cooperation -- A Gravity Model Impact Analysis, Munich, CESifo, Working Paper $n^{\circ} 1970$, April 2007, p.18.

73. Ibid., p. 22.

74. Customs duties on imports averaged 28 percent.

75. See Asia Times, Internet edition, 26 September 2006, http://www.atimes.com/atimes/South_Asia/HI26Df01.html.

76. Gulshan Sachdeva, "India's Attitude towards China's Growing Influence in Central Asia," China and Eurasia Forum Quarterly, Vol. 4, n³, 2006, pp. 23-34. 
cutthroat competition in the search for energy in all corners of the globe in order to meet their soaring demand for energy supplies. Just before the agreement was signed, in November 2005, India's ONGC (Oil \& Natural Gas Corporation) and its counterpart, CNPC (China National Petroleum Corporation) got together for the first time ever to buy a major stake in Petro-Canada's venture in the Syria's al-Furat oilfields. ${ }^{(77)}$ The January 2006 tie-up gave a genuine boost to Sino-Indian energy cooperation. Many other largescale joint operations have since been launched, such as those in Sudan ${ }^{(78)}$ and Colombia, ${ }^{(79)}$ and more recently in the supply of equipment for electricity generation. ${ }^{(80)}$ The idea of two economic giants and new entrants on the international energy chessboard getting together to take on major US, European, and Japanese companies on their favourite hunting grounds of Africa, the Middle East, Latin America, and Central Asia, was no doubt a seductive one for many observers. Nevertheless, as in other areas of bilateral exchanges, the extent of Sino-Indian cooperation in the field of energy seems to have been greatly exaggerated.

First of all, an analysis of the behaviour of Indian and Chinese firms shows that the relationship is more typically characterized by often brutal competition. Since 2004, Indian firms in direct competition with Chinese companies have lost a series of bids for oil projects in Angola, Kazakhstan, Ecuador, and Myanmar. ${ }^{(81)}$ In a much rarer instance of an Indian firm upstaging a Chinese firm with much greater experience in this field, ONGC Videsh Limited (OVL, the foreign operations arm of ONGC) outbid SINOPEC (China Petroleum \& Chemical Corporation) to acquire Imperial Energy, a British firm that controlled parts of oil projects in Russia and Kazakhstan, for $\$ 2.6$ billion. ${ }^{(82)}$ How could competition be avoided when securing foreign energy supplies has become a key national priority for both giants? During the first half of this century, India and China will remain largely dependent on coal, which they have in large quantities within their territories. ${ }^{\left({ }^{(3)}\right)}$ Their dependence on external sources for oil and gas is expected to continue increasing sharply if both countries keep growing at the rate they have in recent years. The International Energy Agency projects that India's dependence on foreign energy sources will rise from 73 percent (in 2006) to 91.6 percent by 2020. In China, which was energy self-sufficient until the mid-1990s, dependence on foreign sources is expected to rise to 50 percent in 2010 and to 77 percent in $2030 .{ }^{(84)}$ Thus the two countries' national independence relies in part on access to new foreign energy sources.

This increasing demand for hydrocarbons comes at time of great uncertainty on the global oil scene. As latecomers,
China and India are not finding it easy to take on the major oil giants, who have dominated the industry for more than a century with remarkable stability. Whatever might be said of their exploits in Africa, reports of which have eaten up acres of newsprint in recent years, Chinese and Indian firms are forced to make astronomical bids to gain entry into areas where Western and Japanese companies have traditionally held dominance. India and China have also had to deal with countries deemed untouchable (albeit only in recent years) by Western and Japanese firms for political reasons. Beijing and New Delhi appear to be less worried about moral arguments (as indeed Western governments had been until recently), but this type of cooperation is not without political cost, as demonstrated by the criticisms hurled at China over its role in the Darfur crisis. ${ }^{(85)}$ Sudan accounts for six percent and five percent, respectively, of China's and India's foreign oil supplies, ${ }^{\left({ }^{(6)}\right)}$ and the Sudanese government has granted 40 percent of the exploitation rights of its oilfields to China, 30 percent to Malaysia, and 25 percent to India. ${ }^{(87)}$ The Chinese government has been accused of closing its eyes to the Darfur crisis and of economically sustaining the Khartoum regime, which has faced several critical votes in the United Nations. In early 2008, in the run-up to the Olympics in Beijing, Chinese diplomats were forced to shed their reticence and address mounting international criticism over their role in

77. The two sides worked together in extracting, transporting, and refining oil in Sudan. After Western and Japanese firms pulled out over the Darfur conflict, China, Malaysia, and India took charge of oil-related works in the country.

78. CNPC and ONGC, though subsidiaries, invested $\$ 850$ million in a 50 percent stake in Omimex Colombia (US subsidiary of Omimex Resources) with oil and gas extraction in South America.

79. In August 2008, the Indian Reliance group, along with Shanghai Electric, signed a fiveyear industrial cooperation agreement envisaging design, production, and marketing of electricity generation equipment; http://www.2point6billion.com/2008/08/18/indiachina-us3bn-energy-pact/.

80. In August 2005, China National Petroleum Corporation paid $\$ 4.18$ billion to acquire Canadian-owned PetroKazakhstan, outbidding India's Oil and Natural Gas Corporation, which offered \$3.9 billion. See J. Nandakumar, "India-China Energy Cooperation Attaining New Heights," Institute for Defence Studies and Analyses Strategic Comments, 28 November 2005; and on Angola, AFP, 15 October 2004.

81. International Business Time, 28 August 2008.

82. At present, coal accounts for 56 percent of India's energy resources and 74 percent of China's. For estimates, see International Energy Agency, World Energy Outlook 2006, Paris, 2006.

83. World Energy Outlook 2006, op. cit., p. 101.

84. The Indian government has been relatively less exposed to international criticism over its massive investment in Sudan's oil industry.

85. Amounting to 10.3 million tonnes of oil by end 2007. See Business Week, 13 February 2008.

86. Sudan Tribune, 6 March 2006, http://www.sudantribune.com/article.php3?id_article $=14363$.

87. Jason Qian and Anne Wu, "China's delicate role on Darfur," Boston Globe, 23 July 2007; Washington Post, 14 December 2006. 
Sudan. ${ }^{(88)}$ In Burma, the military, economic, and diplomatic support given to the military regime by China and India in exchange for the exploitation of natural gas resources has also drawn fierce criticism from around the world.

Sino-Indian competition is not limited to hydrocarbons; it is equally fierce in the quest for other raw materials both countries lack. Phosphates, iron ore, nickel, lead, scrap iron, aluminium, leather, zinc, and tungsten (despite major domestic resources of these in China's case) are the subject of intense competition, not only between China and India, but also among other big countries. ${ }^{\left({ }^{(8)}\right.}$

Finally, even when large Indian and Chinese energy groups decide to collaborate, there is nothing to indicate that these projects would be conducted in the framework of a strategic and special relationship at the expense of their cooperation with other countries. On the contrary, an analysis of the foreign cooperative ties of the two countries' oil and gas giants shows that their links to European, American, Russian, Japanese, Saudi, and Australian companies and to major developing countries such as Brazil, Chile, Iran, and Venezuela are much longer, more numerous, and sustained. As of late 2006, China National Offshore Oil Corp. (CNOOC) had signed 182 contracts and agreements in the oil domain with 76 companies from 21 countries. ${ }^{\left({ }^{90}\right)}$ Shell, Exxon, Chevron, and Total are CNOOC's major partners, far ahead of any Indian companies. Of CNOOC's 50 oilfields offshore of China, 27 are exploited jointly with foreign companies, but no Indian firm was among them as of late 2006. The same situation pertains with regard to the other oil and gas giant, SINOPEC: no Indian firm figures among its strategic partners, while the company enjoys close cooperation with major Western multinationals in both exploitation and commercialisation. ${ }^{(91)}$ Similarly, there is no indication that China firms are about to overtake the cooperation Indian companies have established with Western and Japanese companies or those from other developing countries. ONGC Videsh, for instance, has much closer links to Brazil's Petrobras, having signed a series of strategic agreements in 2007. ${ }^{(92)}$ Agreements signed with CNPC or SINOPEC are in no way exclusive or different from many others that ONGC Videsh has signed with foreign partners since early this decade. ${ }^{(93)}$ The same holds true for the Indian private group Reliance. ${ }^{\left({ }^{44)}\right.}$ Sino-Indian cooperation in energy is thus devoid of any exclusivity: the importance of recent joint projects they have launched are put in perspective by the older and more sustained ties both sides maintain with other countries. China and India have treated each other as potential alliance partners in recent years for specific projects in the same way as they have other state and private actors on the world energy scene.

Given these facts, it is clear that despite the implementation of a few joint projects in hydrocarbons since 2005, the two countries are far from forging a strategic relationship in energy and raw materials. Cooperation between Chinese and Indian firms appears for now to be more the exception than the rule as the two engage in ruthless competition to secure new foreign energy supplies.

\section{Pragmatic alliances in international economic institutions}

Aware of the quasi-hegemonic role of the United States and Europe in the Bretton Woods institutions created after the end of World War II, Jawaharlal Nehru had, after India's independence in 1947, actively sought Chinese support to counter the weight of the developed countries and to defend the interests of developing ones. The Bandung conference in April 1955, with 29 developing countries represented, was a culmination of this strategy, in which India played a central role. The impossibility of the Chinese Communist regime's participation in the Bretton Woods institutions until the 1970s (when China at last took the seat occupied by Taiwan), as well as the 1962 Sino-Indian war, put paid to any hopes of building a strategic Beijing-New Delhi axis aimed at defending the interests of developing countries. Although China was reintegrated gradually into all international organisations during the 1970s (UN) and 1980s (IMF, World Bank), it was above all with the WTO accession in 2001, at a time of far-reaching reforms to the world trade architecture, that the opportunity for a Beijing-New Delhi axis arose again. The Doha Development Round of the WTO, which commenced in 2001, was marked by strong differences between the developed and developing

88. In Ecomine, various issues, Direction Générale de l'énergie et des matières premières, Ministère de l'Industrie, (Directorate general of energy and raw materials, French industry ministry) http://www.industrie.gouv.fr/energie/publi/f1e_pub.htm.

89. http://www.cnooc.com.cn/yyww/hzsy/dwhz/244281.shtml

90. Shell, ExxonMobile, BP, and MacDonald's as strategic partners of SINOPEC, in http://english.sinopec.com/about_sinopec/our_business/our_partners/ and http://english.sinopec.com/about_sinopec/our_business/sinopec_worldwide

91. See

http://www.ongcvidesh.com/display1.asp?fol_name=News\&file_name=news135\&get _pic $=0 \mathrm{vl} \_n e w s \& p \_t i t l e=\&$ curr_f $=135 \&$ tot_file $=155$

92. Notably with those from Brazil, Italy, Russia, and Venezuela.

93. Report of activities, 2003, 2004, 2005, 2006, 2007.

94. For the main points of negotiations in the agriculture field, see http://www.wto.org/english/tratop_e/agric_e/negs_bkgrnd25_marketframework_e.htm. 
countries, with India playing a particularly active role in defending the latter's interests.

The Doha Round collapsed over a number of issues: ${ }^{(95)}$

- Farm subsidies in developed countries, especially EU member-states;

- "Special products" that allow developing countries flexibility by according the right to protect national producers judged to be supplying goods crucial for food security and rural development;

- Special safeguard mechanisms to allow developing countries to temporarily increase protectionist duties on some basic farm products such as wheat and rice so as to protect their farmers during a time of rapid rise in imports;

- Developed countries' wish to include some minimum social and trade union conditions in the WTO framework;

- The possibility of defending fisheries in developing countries through subsidies authorised in the WTO framework;

- Finally, the degree and speed of opening of the services sector in developing countries.

As a newcomer in the WTO, China kept a low profile in the Doha Round. Nevertheless, Beijing clearly aligned itself with New Delhi's stand on each of the issues, letting India play the leader's role during ministerial conferences. China also weighed in to back India at crucial moments in the negotiations. For instance, during the last ministerial of the Doha Round at Geneva on 29 July 2008, China's support for India was crucial after Brazil defected and positioned itself behind the developed countries. In April 2007, during a meeting in Beijing between Commerce Minister Bo Xilai and his Indian counterpart, Kamal Nath, the two sides issued a joint declaration voicing a strong common position in defence of developing countries' interests. ${ }^{(96)}$

China and India have also defended shared stands in international negotiations on climate change, especially as regards the establishment of rules that will take effect by the end of the first stage, i.e. 2012, as envisaged in the Kyoto Protocol. The two countries have made common cause over the past several years, affirming this entente forcefully at the last Climate Change Conference in Bali in December $2007^{\left({ }^{97}\right)}$ by rejecting all attempts by developed countries (except the United States) to impose quotas on the emission of greenhouse gases. The two countries also joined hands to reject the principle (proposed notably by France) of a tax on imports of products from countries that have high rates of greenhouse gas emissions. China and India also jointly proposed the setting up of a fund financed by countries "histor- ically" responsible for the greenhouse effect (United States and Europe) to help fund innovations and technology transfers to reduce carbon dioxide emissions.

Seeing the impact of such alliances between India and China, several analysts have spoken of a new era in international economic organisations, especially the WTO. Unthinkable only 15 years ago, given the state of their bilateral ties and China's limited participation in international economic organisations, such alliances could be repeated in future and could change the current power equations in international negotiations. Nevertheless, such China-India alliances can be expected to be limited to specific issues and remain pragmatic, and are unlikely to lead to the formation of a systematic axis for defending developing countries. The numerous geostrategic rivalries examined in the first part of this paper limit the extent of such alliances, which are still largely dictated by specific convergences linked to the defence of national interests and limited to some economic issues. The lack of alliance between the two countries on other matters, such as the reform of the United Nations and the IMF, was demonstrated by China's attitude toward India's aspirations to obtain a permanent seat in the UN Security Council.

\section{Conclusion}

In analysing various facets of Sino-Indian relations, the effort here has been to show that behind the media and official hyperbole over warming diplomatic and economic ties since the early 1990s, the bilateral process remains entangled in a series of geostrategic and economic rivalries. Beijing-New Delhi relations continue to be dogged by mutual suspicion inherited from the 1962 war, itself the result of the clash of mutually irreconcilable nationalisms and ambitions toward the Asian scene. In 1959, i.e. three years before the start of the war, Jawaharlal Nehru had told Edgar Snow in an interview that "the basic reason for the Sino-Indian dispute was that they were both 'new nations' in that both were newly independent and under dynamic nationalistic leaderships, and in a sense were 'meeting' at their frontiers for the first time in history." (98) The Indian historian Ramachandra Guha takes this further, insisting that the India-China conflict "was a clash of national myths, national egos, national
95. The Hindu, 16 April 2007.
96. The Hindu, 18 December 2007.
97. Edgar Snow, op. cit, p. 761.
98. Guha, op. cit, p. 336. 
insecurities and - ultimately and inevitably - national armies." ${ }^{(9)}$

The geopolitical context has of course changed greatly today, but the clash of two nationalisms on the Asian scene continues to influence Sino-Indian relations. Some underlying tensions felt during the 1950s, such as competition for Asian leadership, and Beijing's fear of military containment and of a US-India alliance, continue to weigh heavily on bilateral ties today. The 1950s also left behind heavy baggage in the form of the Tibet issue, boundary demarcation, and SinoPakistan relations. India's military defeat in 1962 has remained one of the greatest national humiliations of independent India. It also completely destroyed the capital of confidence placed in the neighbouring country by Nehru, one of the fathers of modern India, and exposed the contradictions and limits of India's pursuit of the policy of non-alignment. Nearly half a century later, the shockwaves of that war have yet to wane in India's political and military establishment. Every time tensions increase between the two counties, the past rises up to haunt the spirits of Indian leaders.

A relationship based on pragmatism is the best that can emerge from this loaded and complex heritage and its three decades of "freeze." As the above analysis indicates, Beijing-New Delhi ties today are subjected more to tensions that pit them against each other than joint projects that bring them closer together. Normalisation of relations does not, therefore, imply the emergence of a genuine strategic partnership; the hypothesis according to which development of bilateral exchanges help sweep away rivalries, tensions, and mutual suspicions appears to lack credibility. As Brahma Chellaney of the Centre for Policy Research has said about Sino-Japanese ties, "200 billion dollars' bilateral trade between China and Japan do not guarantee moderation and restraint in bilateral relations when strategic animosities remain unresolved." (100) The "gentle commerce" between people and nations, so dear to Montesquieu and Adam Smith, today helps China and India to (re)discover each other, ${ }^{(101)}$ and to act together on specific issues in some matters of energy and environment and in the WTO framework. But that does not amount to a magic wand that will wish away the numerous problems that currently weigh down bilateral relations, as well as both countries' hegemonistic ambitions in Asia.

In other words, India and China are well on the way to changing the world. ${ }^{(102)}$ But they do so separately, through the emergence of their respective economic and military might, rather than through a strategic partnership, which for the moment remains more a pious declaration than a reality.

\section{-Translated by N.Jayaram}

